\title{
INTELLECTUAL PROPERTY RIGHTS IN NANOTECHNOLOGY: WHO OWNS THE ATOMS?
}

\author{
DIREITOS DE PROPRIEDADE INTELECTUAL EM \\ NANOTECNOLOGIA: QUEM É DONO DOS ÁTOMOS?
}

\author{
Daniel Francisco Negao Menezes ${ }^{1}$ \\ Ernani Contipelli ${ }^{2}$
}

Recebido em: 24/01/2021 Aceito em: 05/08/2021

negao.menzes@gmail.com ernanicontipelli@gmail.com
Abstract: In Latin America, under the premise of enhancing economic competitiveness, there has been an exponential increase in investments in the development of nanotechnologies. In this context, the discussion about intellectual property rights concerning nanotechnology is increasingly central to public debates. However, in comparison with the attention that this issue has attracted in both public and private contexts, there has been little academic analysis published on property rights and nanotechnology. This article problematizes the application of property rights in the development of nanotechnologies through a critical literature review of the existing literature on the topic. From this analysis, the key issue of the restrictions imposed on the application of patents on 'first generation' products is analyzed. This question pits those who claim rights to royalties to recoup $R$ and $D$ investments made to develop these technologies against those who argue for open access to science and technology.

Keywords: nanotechnology; intellectual property rights; patents; WTO; science policy.

Abstract: Na América Latina, sob a premissa de aumento da competitividade econômica, houve um aumento exponencial dos investimentos no desenvolvimento de nanotecnologias. Nesse contexto, a discussão sobre direitos de propriedade intelectual relacionados à nanotecnologia é cada vez mais central nos debates públicos. No entanto, em comparação com a atenção que este tópico atraiu em contextos públicos e privados, existem poucas análises acadêmicas publicadas sobre direitos de propriedade e nanotecnologia. Este artigo problematiza a aplicação dos direitos de propriedade no desenvolvimento de nanotecnologias por meio de uma revisão bibliográfica crítica da literatura existente sobre o assunto. A partir dessa análise, é analisada a questão-chave das restrições à aplicação de patentes em produtos de "primeira geração". Essa questão coloca aqueles que reivindicam direitos de royalties para recuperar os investimentos em P\&D feitos para desenvolver essas tecnologias com aqueles que defendem o acesso aberto à ciência e tecnologia.

Palavras-chave: nanotecnologia; Direito de propriedade intelectual; patentes; OMC; política científica.

\section{INTRODUCTION}

Since the mid-2000s, nanosciences and nanotechnologies (NyN) occupy an increasingly important place in the research and development $(R \& D)$ agendas of countries, both in the public and private sectors. Together with biotechnology and information and communication technologies (ICT), they are part of the converging technologies, which currently attract the interest of scientists, academics, businessmen and officials. At present, NyNs are used in different productive sectors, such as health, agri-food, energy, the environment, electronics and telecommunications.

The first research in NyN dates back to the mid-1990s, when the United States, the European Union and Japan began to promote R\&D policies for this field of knowledge. In the middle of the first

\footnotetext{
${ }^{1}$ Universidade Presbiteriana Mackenzie. São Paulo. Brasil

${ }^{2}$ International Business School the Hage. Holanda.
} 
decade of the 21st century, these developments assumed a privileged place in the research budgets, protected in a market that, by 2015, will reach a size close to 3100 million dollars (Palmberg et al. 2009). Thus, Brazil, Mexico and Argentina, and to a lesser extent the rest of the Latin American countries, have launched initiatives that, in one way or another, propose nanotechnology as a strategic area for the development of nations (Foladori et al. 2012 ).

The implementation of programs in this area is closely related to the launch of the National Nanotechnology Initiative in the United States, which through institutional agreements with the World Bank and the Organization for Economic Cooperation and Development (OECD) promoted between countries Latin American generation of developments in these areas (Foladori and Invernizzi 2011).

Following the large investments and expectations placed on these developments (similar to other cross-cutting technologies such as information technology, electronics, biotechnology, etc.), the discussions around the returns to investment in R\&D through the application of Intellectual property rights (IPR) has become a central issue that generates tensions and controversies between the different actors involved in the R\&D processes, regarding events that can be patented, and the scope of the regulatory mechanisms of the Global and national patent system.

On the one hand, most public and private companies and institutions understand patents as the only instrument capable of guaranteeing and ensuring the return on investments made in R\&D. On the other hand, both from the productive sector and from the scientific-technical and academic one, it is argued that the application of patents to certain events limits the development of nanotechnological products, while conditioning autonomous innovation processes, particularly in peripheral countries.

Despite the concern that these processes generate in different areas and the importance attributed to the privatization of scientific knowledge about the processes of economic and social development, academic and scientific-technical production related to the operation and scope of property rights Intellectual in NyN is still scarce, highly dispersed and aggregated.

Within the framework of the Social Studies of science and technology, as a way of contributing to the debate from a constructivist and sociotechnical perspective, it is proposed to problematize the scope and limitations of the application of IPR in the development of nanotechnology in peripheral countries, to based on the critical review of a set of academic articles referring to the implications of IPR in the field of N\&I.

Given the importance assigned to intellectual property policies in the agenda, the analysis integrates and complements conceptualizations belonging to the constructivist approach, with notions in terms of policy and negotiating power. This perspective allows us to analyze the process of knowledge production and unravel the complex network of alliances, strategies and social actors involved in the construction of scientific-technological knowledge (Licha 1995), while understanding that technology and politics constitute each other, as two sides of the same coin (Bijker 2005). At the same time, politics can be understood as a technology of social organization and intervention on society (Serafim and Dias 2010).

Based on the search, selection and systematization of the scientific-technical production referred to the relationship between DPI and $\mathrm{NyN}$, this work is organized as follows: firstly it describes the development process of the $\mathrm{NyN}$ and the role of patents of patenting, then the discussions on the 
issue produced by multilateral trade organizations are drawn up; thirdly, the different approaches are distinguished in the approach of the intellectual property rights issue for the $\mathrm{N} \& \mathrm{I}$ and subsequently the different positions and approaches are compared based on the selection of a set of studies related to the application of IPR in nanotechnological developments ; Finally, a series of reflections and questions arise that arise from this approach to IPR in the field of nanoscience and nanotechnology.

\section{CONTROVERSIES AROUND THE APPLICATION OF PROPERTY RIGHTS SYSTEMS IN NANOTECHNOLOGICAL PRODUCTION}

The different products obtained within the framework of the NyN - similar to any other discovery - entered into a patenting process, which grew rapidly in developed countries. Between the beginning and the middle of 2000 , in the United States - the country that has made the greatest investments in these developments - the number of patents grew exponentially, at a rate of $75 \%$, with most applications corresponding to patents of first generation products.

At present, nanotechnology processes and production belong mostly to what is called 'first generation' and include applications for work at an atomic scale such as scanning microscopes or the synthesis and isolation of 'simple' molecules that are incorporated into various products such as cosmetics and paints, among others.

The 'first generation' is composed of: a) particles existing in nature that are isolated for use as both a final product or nanointermediary and b) a set of technologies whose design allows the matter to be worked at a molecular scale, represented by the electron microscope of swept. Both processes allow to continue with the development of new technologies, a phenomenon that increased significantly as a result of the improvement in the techniques of observation and isolation of particles for later use.

From the first generation it is expected to obtain - through a bottom-up process - second and third generation developments, which mean products of greater relative complexity (Bowman 2007).

First generation products represent the main components for the NyN production chain. If these products are under the protection of a patent, then the path from one generation to another, which in itself is not so simple and linear, is complicated because difficulties are generated in accessing nanointemediaries (precursors) for subsequent developments.

For this reason, the process by which patents allow the registration of different types of molecules became an object of controversy among the actors involved in the R\&D processes and renews questions regarding the virtuous relationship between these processes and IPRs. (Bowman 2007; Tullis 2012). On the one hand, some companies and R\&D institutions defend the collection of returns on the investment made, while others, which depend on first generation products for future developments, question the validity of this discovery protection mechanism, once the expectations of investments, both public and private, seem to be set on the second and third generation of products. 


\section{CONTROVERSIES OF THE APPLICATION OF PATENTS TO THE NYN}

The application of IPR is deepened and becomes more relevant during the 1990s, in correspondence with neoliberal policies and increasing privatization of scientific and technical knowledge prevailing at international level and aimed at ensuring the returns on R\&D investments through the protection and subsequent collection of royalties for the capital invested in the innovation processes. This growing importance of IPRs has gone hand in hand with the promotion of mechanisms and strategies to strengthen the local patent systems that central countries have carried out within organizations such as the World Trade Organization (WTO) and the World Organization Industrial Property (WIPO).

During the last years, the actors involved in the R\&D processes in NyN gave rise to a phenomenon known as 'compulsive patenting', by promoting the registration of first generation molecules, which affects the possibility of continuing to develop base products nanotechnology The regulations imposed by IPRs on $\mathrm{N} \& \mathrm{I}$ and issued by multilateral trade organizations not only limit innovations and subsequent developments in the field of nanotechnology in the central countries themselves, but also accentuate inequality between these countries and peripherals, that they are forced to adapt their intellectual property laws in accordance with the WTO standards, mainly in relation to property rights and technology transfer (Chimuris and Garrido Luzardo 2007). In this regard, the actions of the agreement on "Aspects of trade-related intellectual property rights" (TRIPS) created within the WTO are key to understanding the origin and subsequent development of the dispute between IPR and R\& D in NyN.

The United States Patent and Trademark Office (USPTO) has allowed us to patent all kinds of first-generation developments of $\mathrm{NyN}$ products. However, with the passage of time, different researchers raised a series of problems derived from the patent for the development of products of greater nanotechnological complexity. While the fact of registering and patenting developments is common to other fields of knowledge, the perspectives generated by the NyN have resulted in a more aggressive strategy by the different $R \& D$ institutions to patent. This strategy, focused on the defense of investments made, has become a difficulty for users of nano-intermediaries who need to resort to patented developments to continue with subsequent $R \& D$ processes.

In this way, the difficulty is that the development of second generation products requires the payment of authorization of use before the USPTO for royalty purposes to the owners of the patents that sometimes exceed the investment necessary for the development of new products. Against this background, in many cases a research project has been abandoned in NyN (Tullis 2012).

Although at the R\&D level of second generation products, 'compulsive patenting' is a relevant issue, the problem actually permeates the entire nanotechnology industry. Hence, various industryrelated actors have referred to the need for a new discussion on material that can be patented before multilateral trade organizations (Bowman 2007). In this regard, in the TRIPS discussions revolve around two axes: a) the 'originality' approach to patentable matters and b) the pressures around the treatment of the issue within the WTO. 
In relation to the first topic, analysts point out a series of questions about the possible materials to be patented. Based on the WTO definition regarding the registration of products established in the regulations, Bowman (2007) points out that it is not clear regarding the difference between discovery and invention. Thus, in the case of $\mathrm{NyN}$, the fact of registering molecules that in many cases are found naturally, but that are visualized through specific instruments, raises questions about whether visualizing them can be considered or not an inventive activity.

Around the second point, the discussion around the patents in $\mathrm{NyN}$ is largely marked by the pressures of the central countries and the $R \& D$ laboratories of transnational firms. At international level, the resources put into play are recreated and rearticulated by signing agreements with other countries and adapting national legislation, on the registration and granting of patents for nano products, to the regulations and directives issued by the organizations multilateral trading. Thus, the amount of resources put into play and the search for returns on investments - through IPR - aligns and coordinates the R\&D agendas of the participants in the nanotechnology system.

At the same time, in peripheral countries, the majority of analysts and policy makers point out the ability of $\mathrm{N} \& \mathrm{I}$ to generate competitive conditions through endogenous development processes in the region, which would allow them to insert themselves into windows of opportunity and take advantage of the space that opens at first with the emergence of disruptive technologies, such as in other emerging technologies such as biotechnology. However, in that case the capabilities of peripheral countries to innovate have been limited by the pressures that transnational corporations exert on the WTO for the application of legal mechanisms that guarantee returns on investment in $R \& D$. These companies form techno-economic networks that allow them to act and pressure within the scope of the policies established by the WTO and through them in the actions of national governments.

In the region, this process of privatization of scientific-technological knowledge has been accompanied by policy recommendations in science and technology where an offensive and linear vision predominates, inspired by a conception of technological determinism, which considers that development in this area conditions more than any other aspect of change and social structures.

The affiliation by Latin American countries to global trade agreements, particularly TRIPS, directly influences the use and commercialization of N\&I. An inherent difficulty in TRIPS is that this agreement does not reflect the complexity of this field and in general does not allow access and generation of nanotechnological products within an equality framework, which intensifies the processes of inequality that compromise the future of scientific development -technical and commercialization of nanotechnological products and processes in the periphery nations.

These issues, commonly, are not part of the public policy agenda of science, technology and innovation (CTI) of Latin American countries, which without further discussion on the definition regarding the material that can be registered under national patent systems, try uncritically replicate a model of "compulsive patenting", bypassing the implications of these mechanisms on the use and appropriation of knowledge and the debate on the social utility of scientific-technological processes. 


\section{PREVAILING APPROACHES TO APPROPRIATION AND USE OF SCIENTIFIC- TECHNICAL KNOWLEDGE FOR NANOTECHNOLOGICAL DEVELOPMENT}

In addressing the processes of appropriation and use of scientific knowledge in NyN, two aspects are distinguished: one that refers to the mechanisms of appropriation of technological innovations, with emphasis on the modes of regulation from an institutional and economic perspective and another, which It comes from discussions regarding the appropriation and social use of knowledge within the framework of the social studies of Science, Technology and Society (CTS).

In the first approach, studies from a neo-institutionalist perspective predominate, which focus on the mechanisms of appropriation of technological innovations and modes of regulation and basically interrelate the number of patents with economic development. In most of the works that are registered in this aspect, the authors analyze the changes produced - especially in the central countries - from the strengthening of the patent system and the behavior of the various actors in the face of the privatization of scientific knowledge. In this sense, Ayala Espino (1999, p. 221) points out:

[...] Los cambios en los derechos de propiedad juegan un papel estratégico en el intercambio porque pueden cambiar el desempeño de la economía, redefiniendo la distribución de la riqueza y el poder político entre agentes, y aun modificando su posición relativa en las estructuras de poder. En cualquiera de estos casos los agentes pueden ganar o perder su posición original en la distribución inicial del ingreso y el poder.

Within this approach, a heterogeneous set of studies that emphasize the consequences of the implementation of IPR in developing countries are highlighted. Authors such as Correa (1997), Abarza and Katz (2002), Forero-Pineda (2006) and Deere (2009) point out the disadvantages faced by peripheral countries in relation to the implementation of TRIPS, however agreeing on the need to adapt National frameworks to international regulations. In general, they argue that North-South analyzes of the 'advantages' and uses of IPRs do not consider structural issues for the development of these countries. Thus, many of the attempts by countries of the global south to generate "own" developments end up not being realized by the pressures exerted by the different international actors.

Other analysts focus on the relationship between IPR and foreign direct investment (FDI) or between the former and the mechanisms of technological cooperation. For example, Correa (1997) and Park and Lippoldt (2008) relate foreign direct investment (FDI) flows to the regulatory systems established by IPRs. While the first advocates local legislation that avoids anti-competitive practices and abuses in the use of IPR, the second finds correspondence between greater national regulations and foreign investment processes. Juma (1999) - among those interested in cooperation - proposes that nations implement measures regarding matters of public interest such as health, while devoting greater efforts to generating mechanisms of technological cooperation between countries.

Although the majority of conclusions and recommendations are based on experiences in areas such as the pharmaceutical industry, biotechnology and biodiversity protection, without explicit references to $\mathrm{N} \& \mathrm{I}$, the trajectory followed so far by property protection systems intellectual in 
nanotechnological developments, indicates that regulations based on IPRs will increase, deepening inequality relations between countries in this field of knowledge.

Within the second approach that is developed in the field of CTS studies, the works that address issues related to N\&S have been increasing year after year. Several authors enrolled in this trend seek to understand the implications of the development of N\&l, by focusing the analysis on a set of political, economic and social dimensions, but without deepening the scope and limitations of patent application mechanisms to the NyN.

Internationally, authors such as Currall et al. (2008) and Evans (2010) analyze the public perception and the role of users within the developments of the NyN. They understand that in the future the processes of legitimation and public appropriation of knowledge will be crucial in the progress of this field. Meanwhile, Jamison (2009) and Cozzens (2011) propose to study the role of $\mathrm{NyN}$ in the construction of more equitable societies, where the need to redistribute new technologies in the context of north-south relations is highlighted.

At the Latin American level, the studies emphasize the role of the NYs for the solution of structural problems in the region (Invernizzi and Foladori 2005, 2008). These authors point out that beyond the supposed benefits that developments in this field could bring (as with biotechnology), N\&N can deepen the processes of inequality and exclusion of countries. In this regard, Invernizzi and Vinck (2009) argue that in Latin American countries when analyzing N\&N, particularities are distinguished as a result of the international division of scientific work and the integration processes of Latin American researchers into the scientific networks of countries central. Within the framework of the Social Studies of science and technology, these authors divide the scientific-academic production into three analysis groups: a) research that refers to the organization and academic scientific dynamics in the processes of knowledge production and artifacts ; b) studies on technological innovation processes: mechanisms, intermediation and interaction processes and cooperation networks and c) works that address the perception of risks and benefits, the processes of participation and democratization of science and technology and the construction of agenda (Invernizzi and Vinck 2009).

Based on this division, within the first group Robles Belmont (2009) and Pérez and Vinck (2009) analyze issues related to the role of scientific networks. The authors conclude that part of the scientific networks constructed are aimed at accessing non-existent material resources in the countries of origin. Within the second group, Hubert and Spivak L'Hoste (2009) argue about the role of instrumental devices and how they model much of the relationships between the research centers, generating in many cases dynamic that do not follow the center-periphery patterns. In the last group there is a heterogeneous set of works that deal with issues related to the consequences of the NYs in the Latin American context and point out the need to discuss and rethink the NYs in the framework of the current economic models. Thus, Invernizzi and Foladori (2005) and Foladori and Invernizzi (2006) reflect on the role of nanotechnologies as a solution to poverty, Foladori and Invernizzi (2009) on ethical issues and Delgado Ramos (2007) on the risks inherent in use of nanoparticles.

In principle, from the analyzes in the field the Social Studies of science and technology it follows that although there are differences between the central countries and Latin America in terms of the analysis perspectives, the studies that have increased considerably they analyze the relations 
between the $\mathrm{NyN}$, the society and the public policies, being still scarce the explicit references to the relation between DPI and NyN. Most research raises moral, ethical and political considerations, and according to Licha's (1995) arguments, there are also public controversies in this field between environmental values and economic priorities, between economic interests and risks to workers' health and of the population, as well as between investment in R\&D and equity.

\section{PROBLEMATIZATION IN THE SCIENTIFIC-ACADEMIC LITERATURE OF THE RELATIONSHIP BETWEEN INTELLECTUAL PROPERTY RIGHTS AND NANOTECHNOLOGICAL DEVELOPMENT}

The scientific-academic literature that specifically refers to the effects of IPRs on nanotechnological developments is still scarce and comes mostly from central countries. In order to analyze how the problem-solution relationships associated with the application of IPR in N\&I are studied and constructed, a set of studies that reflect on the scope and limitations of intellectual property regulations for nanotechnologies are presented below. The analysis took into account a series of dimensions, such as: origin, actors involved, role assigned to patents, USPTO and TRIPS and the solutions proposed by the authors.

This information shows - as noted above - the prevalence of studies belonging to authors from central countries. The majority come from public R\&D institutions and, in general, address issues related to N\&E regulations in the framework of the WTO and the current patent system in the United States. Regarding the actors considered relevant in the construction of the problem, there is a coincidence in all the studies: on the one hand, the companies and universities involved in the R\&D processes and on the other, the State, as responsible for administering the system of patents and guarantee the patenting process. The authors understand that the main function of the States is to ensure the return of investments made for nanotechnology-based developments without distinguishing, in the case of universities, if the origin of the funds is public or private.

On the contrary, Chimuris and Garrido Luzardo (2010) emphasize the role of the State as guarantor of endogenous development processes and the problems of peripheral countries when adopting the WTO directives on IPR, since it considers that build a patent system that benefits the institutions of the central countries and accentuates the processes of inequality in Latin America.

In the role granted to patents there is also a coincidence on the part of the authors of the central countries, which, based on the postulates of economic neo-institutionalism, affirm that they represent a way to safeguard the resources put into play for nanotechnological developments. Although Bowman (2007) considers that IPR systems are central to the profit-making of companies, he warns that it is necessary to take into account a minimum of considerations regarding the access of first generation products, in order to cushion the exclusion processes that can be generated through these systems.

The works that refer to the role of the USPTO indicate that in order for this Office to approve a patent without generating major conflicts, its adaptation to the dynamics of knowledge production of the NYs is required, so that they can resolve the deficiencies associated with the lack of experience in 
the registration of certain nanotechnology-based products and the gaps in current legislation for this field of knowledge.

On the role of TRIPS, Bowman (2007), in line with the role granted to patents, mentions the need to recreate within these agreements the conditions that serve as a starting point for this type of development. He proposes that the WTO ensure access to a set of 'first generation' materials, so that countries can use them in later developments to solve social problems. In this way, a legal framework would be generated where the requirements of investors in $\mathrm{NyN}$ are balanced with the needs of social inclusion processes.

On the other hand, Chimuris and Garrido Luzardo (2010) point out the difficulties that are generated in the countries of the region to adapt their regulations to the requirements of the WTO and argue for the particular case of Uruguay, as through different negotiations this The country has been adapting part of its legislation, and signing agreements and treaties that leave it at a disadvantage in the use and appropriation of nanotechnological developments.

Finally, regarding the proposed solutions, the first set of authors coincide in the role of the State in the generation of a new regulatory framework or in the use of existing tools, as a starting point to prevent compulsive patenting of first generation products.

In summary, the majority of studies recognize the tension and problems that arise when applying IPRs to new convergent technologies, such as NyN. Most authors emphasize the conflicts that are generated in global and national institutions, and the need to adapt national regulatory frameworks to international standards, in order to ensure the application of IPRs and propose the need for debate within the multilateral trade organizations on patenting processes.

Within this framework, it is possible to ask about the capacity of the States and the mechanisms of access and participation of all the countries in these organizations, as well as the power and margins of negotiation and the possibilities of generating alternative visions to the current systems of intellectual property that incorporate the conditions and development needs of peripheral countries. To do this, as Licha (1995) puts it, it is perhaps necessary to rediscover and critically rethink the hegemonic concepts and visions of property, law and justice.

\section{FINAL REFLEXIONS}

In conclusion, a series of reflections are presented below regarding the controversies associated with the application of intellectual property rights to nanotechnological developments, the treatment of this issue within multilateral trade organizations and the processes of innovation in $\mathrm{NyN}$ in peripheral countries.

First, it should be noted that the literature referring to property rights in NyN is scarce and dispersed. In her studies predominate the neo-institutionalist approach, which privileges the analysis of the mechanisms of appropriation and use of scientific-technological knowledge, the modes of regulation and the interrelation between development and number of patents. 
The analysis shows the existence of a controversy regarding the restrictions imposed by the payment for the application of a patent for the use of the 'first generation' to continue advancing in the $R \& D$ processes of subsequent nanotechnological products, which are faced by on the one hand to those who claim the rights to remuneration for royalties in $R \& D$, and on the other, to those who raise free access to scientific-technical knowledge.

From the progressive privatization of technical scientific knowledge, this conflict is recreated in the WTO within the pressure exerted by transnational corporations and governments of central countries to ensure the returns on investments in R\&D made, which impose the revision of the national legislation and regulatory frameworks referring to intellectual property rights, in order to adapt it to the regulations and recommendations emanating from multilateral trade organizations.

Conflicts deepen in the case of companies and R\&D institutions in Latin American countries, which generally face greater restrictions for access to nano intermediary components, which allow them to continue advancing in the development of $\mathrm{NyN}$. In order not to lag behind the nanotechnological advances and continue the research and development of nanotechnological production, these companies and institutions reorient their lines and programs through the articulation via agreements with transnational companies and institutions of the central countries. But, this relationship is proposed in terms of 'subordinate integration', since the companies and national institutions of the peripheral countries access information and developments that they would hardly reach by themselves, and through these linkages they participate in exchange spaces that facilitate the learning and interaction processes in the use of technology and appropriation of techniques.

Finally, in a framework of strong competition and investment in NyN at a global level and taking into account the importance attached to these technologies in development processes in peripheral countries, it is possible to ask about the treatment and agenda of the issue in the blocks Latin American regional institutions such as Mercosur (Southern Common Market) and Unasur (Union of South American Nations), as they are a space to channel discussions about the appropriation and use of scientific-technical knowledge at the regional level and the possibility of addressing common strategies such as a tool that makes possible the use of the $\mathrm{NyN}$ in endogenous development processes with social inclusion.

\section{REFERENCES}

Abarza, J.; Jorge K. (2002) Los derechos de propiedad intelectual en el mundo de la OMC. Serie Desarrollo productivo, 118. Santiago de Chile: Comisión Económica para América Latina y el Caribe Cepal.

Ayala Espino, J. (1999) Instituciones y economía. Una introducción al neoinstitucionalismo económico. México D.F.: Fondo de Cultura Económico.

Bijker, W. (2005) ¿Cómo y por qué es importante la tecnología? Redes 11 (21): 19-53. 
Bowman, D. (2007) Patently obvious: Intellectual property rights and nanotechnology. Technology in Society 29 (3): 307-315. doi.org/10.1016/j.techsoc.2007.04.009

Chimuris, R.; Lydia, G. L. (2007) El control extranjero de las nanotecnologías mediante los derechos de propiedad. El caso de Uruguay. Theomai: estudios sobre sociedad, naturaleza y desarrollo 16 (5): 56-68.

(2010) La propiedad intelectual en el cruce con las nanotecnologías: reflexiones en voz alta. En Las Nanotecnologías en Uruguay compilado por Adriana Chiancone y Guillermo Foladori, 123-135. Montevideo: ReLANS-Universidad de la República.

Correa, C. M. (1997) New intellectual standards for intellectual property: Impact on technology flows and innovation in developing countries. en Science and Public Policy 24 (2): 79-92.

Cozzens, S. (2011). Building Equity and Equality into Nanotechnology. Nanotechnology and the challenges of Equity, Equality and Development, editado por Susan E. Cozzens y Jameson M. Wetmore, 433-446.

Currall, S. C.; Eden, K.; Neal, L.; Juan, M.; Stacey, T. (2008). What drives public acceptance of nanotechnology? Nature Nanotechnology 1 (3): 153-155. doi.org/10.1038/nnano.2006.155

Deere, C. (2009). The Implementation Game: The TRIPS Agreement and the Global Politics of Intellectual Property Reform in Developing Countries. Oxford University Press.

Delgado Ramos, G. C. (2007). Sociología política de la nanotecnología en el hemisferio occidental: el caso de Estados Unidos, México, Brasil y Argentina. Revista de Estudios Sociales 27: 164-181.

Evans, N. G. (2010) Speak No Evil: Scientists, Responsibility, and the Public Understanding of Science. NanoEthics 4 (3): 215-220. doi.org/10.1007/ s11569-010-0101-z

Foladori, G.; Invernizzi, N. (2011). Implicaciones sociales y ambientales del desarrollo de las nanotecnologías en América Latina y el Caribe. México y Curitiba, Brasil: ReLANS e, IPEN.

(2009). Las nanotecnologías en la crisis mundial. Polis 8 (23): 281-298

(2006). As nanotecnologias como solução à pobreza?. Inclusão Social 1 (2): 66-72.

Foladori, G.; Figueroa, S.; Záyago-Lau, E.; Invernizzi, N. (2012) Características distintivas del desarrollo de las nanotecnologías en América Latina. Sociologias 14 (30): 330-363. doi.org/10.1590/s1517-45222012000200011 
Forero-Pineda, C. (2006) The impact of stronger intellectual property rights on science and technology in developing countries. Research Policy 35 (6): 808-824. doi.org/10.1016/j.respol.2006.04.003

Hubert, M.; Spivak L'Hoste, A. (2009) Integrarse a las redes de cooperación en nanociencias y nanotecnologías. El rol de los dispositivos instrumentales. Redes 15 (29): 69-91.

Invernizzi, N.; Vinck, D. (2009) Nanociencias y Nanotecnologías en América Latina. El desafío de articular la variedad de los estudios sociales sobre las nanociencias y las nanotecnologías. Redes 15 (29): $42-47$.

Invernizzi, N.; Foladori, G. (2008) Nanotechnology's Controversial Role for the South. Science, Technology \& Society 13 (1): 123-148. doi.org/10.1177/097172180701300105

(2005). El despegue de las nanotecnologías. Ciencia Ergo Sum, 12: 321-327. Jamison, Andrew. 2009. "Can nanotechnology be just? On nanotechnology and the emerging movement for global justice". NanoEthics 3 (2): 129-136. doi.org/10.1007/s11569-009-0064-0

Juma, C. (1999) Intellectual property rights and globalization: implications for developing countries. Science, technology and innovation discussion Paper 4: 1-22.

Licha, I. (1995) Perspectivas de los estudios sociales de la ciencia y la tecnología. Redes 2 (4): 129138.

Palmberg, C.; Dernis, H.; Miguet, C. (2009). Nanotechnology: and overview based on indicators and statistics. OECD STI working paper. http:// www.oecd.org/sti/inno/43179651.pdf doi.org/10.1787/223147043844

Park, W. G.; Lippoldt, D. C. (2008). Technology transfer and the economic implications of the strengthening of intellectual property rights in developing countries OECD Trade Policy Working Paper No.

http://www.oecd.org/

officialdocuments/publicdisplaydocumentpdf/?doclanguage=en\&cote=tad/tc/ wp\%282007\%2919/final. doi.org/10.1787/244764462745

Pérez, C. B.; Vinck, D. (2008). El Rol de la Comunicación en la Co-Construcción de Conocimiento y de Redes de Vinculación y Transferencia en Nanotecnología. Ponencia presentada en 3er simposio internacional en Comunicación del Conocimiento y Conferencias. Orlando, Florida.

Robles, E. B. (2009) Las redes científicas como respuesta a la emergencia de las nanociencias y nanotecnologías. Redes 15 (29): 93-111. 
Serafim, M.; Dias, R. (2010) Construção Social da Tecnologia e Análise de Política: estabelecendo um diálogo entre as duas abordagens. Redes, 16 (31): 61-73.

Tullis, T. K. (20120 Current intellectual property issues in nanotechnology. Nanotechnology Reviews 1 (2):189-205. doi.org/10.1515/ntrev-2012-0501 